\title{
Effects of spring headfires and backfires on tallgrass prairie
}

TERRENCE G. BIDWELL, DAVID M. ENGLE, AND P. LARRY CLAYPOOL

\section{Abstract}

We compared responses of tallgrass prairie vegetation to late spring headfires and backfires on a moderately stocked 2.4 A UM $\mathrm{ha}^{-1}$ ) shallow prairie range site $15 \mathrm{~km}$ southwest of Stillwater, Oklahoma. We replicated treatments 4 times in a randomized complete block design on $10 \times 20$-m plots oriented with the prevailing wind direction. Treatment factors included burning treatments (headfire, backfire, and unburned check) and treatment years (1986 and 1987). Herbage standing crop was clipped to ground level in five 0.25- $\mathrm{m}^{2}$ quadrats per plot in June and August and separated into vegetation categories. Standing crop of tallgrasses in August was $21 \%\left(400 \mathrm{~kg} \mathrm{ha}^{-1}\right)$ greater on headfired than backfired plots. Forb standing crop in August was $26 \%\left(98 \mathrm{~kg} \mathrm{ha}^{-1}\right)$ greater on backfired plots than headfired plots. On tallgrass prairie managed for livestock, the area headfired should be maximized within the constraints of the burn prescription. Backfiring in late spring can be used to increase wildlife habitat on small areas.

Key Words: fire behavior, fire effects

Renewed interest in fire as a range management tool has resulted from an increased awareness of the role of fire in maintenance of dynamic grassland ecosystems. Our understanding is somewhat advanced on the effects of season of burning on tallgrass prairie vegetation, but our understanding is incomplete on the effects of other factors such as fire type on grassland vegetation response to fire (Wright and Bailey 1982). Towne and Owensby (1984) and Adams et al. (1986) reported on the response of tallgrass prairie vegetation to long-term repeated seasonal burning. Gibson (1988) reported tallgrass prairie response to frequency of burning. Responses to fire intensity have been documented for woody vegetation (Van Wagner 1973), and more recently for herbaceous vegetation (Armour et al. 1984, Griffen and Friedel 1984, Roberts et al. 1988). The behaviour of headfires and backfires in grasslands differs (Roberts et al. 1988), but we have found no studies which compare the effects of headfires and backfires on herbaceous vegetation in grasslands. Therefore, the objective of our study was to determine if there are differences in response of tallgrass prairie vegetation to late spring headfires and backfires.

\section{Study Area}

The study area is located on the Agronomy Research Range approximately $15 \mathrm{~km}$ west southwest of Stillwater, Oklahoma. Mean annual precipitation is $81 \mathrm{~cm}$, with $24 \mathrm{~cm}$ falling in the early growing season (last 2 weeks of March, April, and the first 3 weeks of May) (Meyers 1982). Precipitation in the 1986 early growing season was $26 \mathrm{~cm}$. Approximately $8 \mathrm{~cm}$ of precipitation was received during the same period in 1987 . The study area is located on a shallow prairie range site within the Central Rolling Red Prairies Land Resource Area (USDA Soil Conservation Service 1981). The soils are Grainola clay loam with a clay B horizon (Grainola series) and are members of the fine, mixed thermic family of Vertic Haplustalfs. Dominant grasses include big blue-

\footnotetext{
Authors are assistant professor and professor, Department of Agronomy, and professor, Department of Statistics, Oklahoma State University, Stillwater 74078.

This is journal article J-5521 of the Oklahoma Agricultural Experiment Station.

The authors thank Robert Newsom for assistance with field measurements and data entry supported by National Science Foundation Grant DMS-8712540.

Manuscript accepted 27 July 1989
}

stem (Andropogon gerardii Vitman), switchgrass ( Panicum virgatum L.), indiangrass (Sorghastrum nutans (L.) Nash), and little bluestem (Schizachyrium scoparium (Michx.) Nash). The study area was grazed at a moderate stocking rate $\left(2.4 \mathrm{AUM} \mathrm{ha}^{-1}\right)$ from mid-July to mid-November in 1985 and 1986 before the treatments were applied in the spring of 1986 and 1987. A new set of treatment plots was established in both study years with no grazing after the treatments.

\section{Methods and Materials}

We replicated treatments 4 times in a randomized complete block design on $10 \times 20-\mathrm{m}$ plots oriented with the prevailing wind direction. Treatment factors included burning treatments (headfire, backfire, and unburned check) and treatment years (1986 and 1987). Plots were burned in March and April as growth of $C_{4}$ grasses was beginning, as recommended for tallgrass prairie by Launchbaugh and Owensby (1978). Burning conditions are given in Table 1. Current year's standing crop was measured to determine fire effects on vegetation.

Table 1. Fuel loading and weather conditions for spring headfires and backfires on tallgrass prairie in northcentral Oklahoma, 1986 and 1987.

\begin{tabular}{|c|c|c|c|c|c|c|}
\hline & \multicolumn{6}{|c|}{1986} \\
\hline & \multicolumn{2}{|c|}{ Headfire } & \multirow[b]{2}{*}{ Range } & \multicolumn{2}{|c|}{ Backfire } & \multirow[b]{2}{*}{ Range } \\
\hline & $\bar{x}$ & $\mathrm{SE}$ & & $\bar{x}$ & SE & \\
\hline $\begin{array}{l}\text { Fuel load }(\mathrm{kg} / \mathrm{ha}) \\
\text { Air temp. }\left({ }^{\circ} \mathrm{C}\right) \\
\text { Wind speed }(\mathrm{km} / \mathrm{h}) \\
\text { Rel. humidity }(\%)\end{array}$ & $\begin{array}{r}2981 \\
19 \\
12 \\
40\end{array}$ & $\begin{array}{r}378 \\
2 \\
4 \\
4\end{array}$ & $\begin{array}{c}2544-4052 \\
15-23 \\
5-24 \\
33-51\end{array}$ & $\begin{array}{r}2967 \\
18 \\
11 \\
42\end{array}$ & $\begin{array}{r}493 \\
1 \\
4 \\
3\end{array}$ & $\begin{array}{c}2372-4440 \\
15-20 \\
5-23 \\
34-46\end{array}$ \\
\hline Rel. humidity (\%) & \multicolumn{6}{|c|}{1987} \\
\hline Fuel load (kg/ha) & 4156 & 559 & $3208-5584$ & 4176 & 420 & $3064-5104$ \\
\hline Air temp. $\left({ }^{\circ} \mathrm{C}\right)$ & 23 & 1 & $21-24$ & 24 & 1 & $21-26$ \\
\hline Wind speed $(\mathrm{km} / \mathrm{h})$ & 9 & 1 & $8-10$ & 9 & 1 & $8-10$ \\
\hline Rel. humidity (\%) & 28 & 3 & $21-36$ & 25 & 4 & $18-36$ \\
\hline
\end{tabular}

We clipped herbage standing crop to ground level in five $0.25-\mathrm{m}^{2}$ quadrats per plot in early July (peak of cool-season standing crop) and again in mid-August (peak of warm-season standing crop) (Adams and Anderson 1978, Powell et al. 1978). Clipped samples were separated into 5 categories: (1) tallgrasses including big bluestem, indiangrass, and switchgrass; (2) little bluestem; (3) other perennial grasses and grass-like plants, primarily tall dropseed (Sporobolus asper (Michx.) Kunth.), silver bluestem (Bothriochloa saccharoides (Sw.) Rydb.), scribner panicum (Panicum oligosanthes Schultes), fall witchgrass (Leptoloma cognatum Schult.), rattail grass (Manisuris cylindrica (Michx.) Ktze.), sedges (Cyperus spp.), (Carex spp.), rushes (Juncus): (4) forbs, primarily common broomweed (Gutterrezia dracunculoides (DC.) Blake), trailing ratany (Krameria secundiflora DC.)., western ragweed ( $\mathrm{Am}$ brosia psilostachya DC.), yarrow (Achillea lanulosa Nutt.); legumes, primarily purple prairie clover (Petalostemum purpureum (Vent.) Rydberg), scurfpea ( Psoralea simplex (Nutt.) T. \& G.), wild indigo (Baptisia australis (L.) R., Br.); and (5) cool-season annual grasses, primarily downy brome (Bromus tectorum $\mathrm{L}$.). We selected these 5 vegetation categories because of their relative importance as forage 

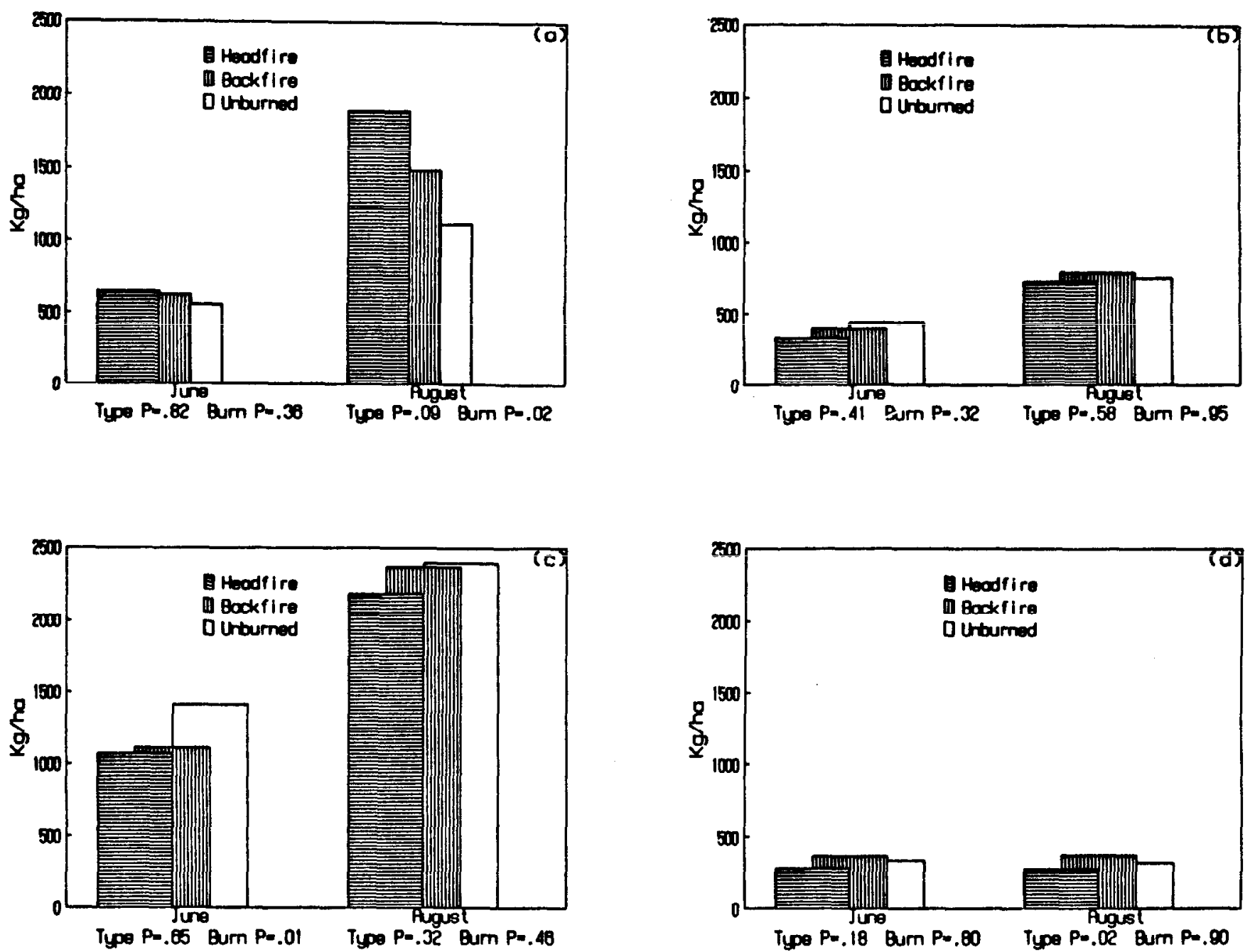

Fig. 1. Standing crop of tallgrasses (a), little bluestem (b), other perennial grasses (c), and forbs (d)

sources for both cattle and wildlife, or because of their expected response to fire. Standing crop data were subjected to analysis of variance with repeated measures in time (split plot $=$ clipping date) and 1 d.f. pre-planned orthogonal contrasts to test for burning treatment effects (backfire vs. headfire = type; burn vs. unburned = burn). Contrast differences were considered statistically significant at the $10 \%$ level of probability.

\section{Results and Discussion}

The only vegetation category of standing crop with a treatmentby-year interaction was total standing crop, so standing crop for other vegetation categories was pooled for 1986 and 1987. Standing crop of several herbage categories differed between fire type and burn treatments. Fire type differences were more evident in August, when the growth rate of herbage in tallgrass prairie slows because of high air temperatures and low available soil water (Powell et al. 1986). Tallgrass standing crop was not different at the June clipping date, but by August headfired plots had greater tallgrass standing crop than backfired plots and burned plots had greater tallgrass standing crop than unburned plots (Fig. 1a).

Little bluestem generally responds negatively to late spring burning (Towne and Owensby 1984). Because of its caespitose growth habit and accumulation of dead plant material within the crown, little bluestem appears especially susceptible to fire injury if conditions are dry (Towne and Owensby 1984). Although we expected little bluestem to respond similarly to backfires because of its growth form, it was not affected by either burning or fire type (Fig. 1b). Pre-burn precipitation was average or above average in both years of our study so soil moisture was apparently adequate to protect the growing points of little bluestem from injury.

Burning reduced the standing crop of other perennial grasses in June, but by August, burned and unburned plots were not different (Fig. 1c). Standing crop of forbs was less on headfired plots than backfired plots in August (Fig. 1d). It is well documented that perennial forbs are responsive to season of burning. Late spring burning in the tallgrass Kansas Flint Hills reduces forbs, whereas winter burning increases forbs (McMurphy and Anderson 1965, Towne and Owensby 1984). The decrease of tallgrasses in backfired plots may have allowed forbs to increase. Also, the mosaic of differential fuel loading combined with the slow rate of spread of backfires may provide forbs with favorable microsites in which to escape lethal temperatures. High levels of fuel moisture (48 $\pm 9 \%$ [SE]), particularly in grazed spots, may prevent efficient combustion of some fuels in backfires, thus providing protection for emerging forbs. However, mulch is a primary factor limiting emergence of annual forbs on tallgrass prairie (Towne and Owensby 1983).

Total standing crop in June and August 1986 was not affected by either spring buiming or fire type (Fig. 2a). In June 1987, however, total standing crop on burned plots was less than on unburned plots (Fig. 2b). The response may be explained by an abnormally dry March and April, the effects of which did not carry over to 

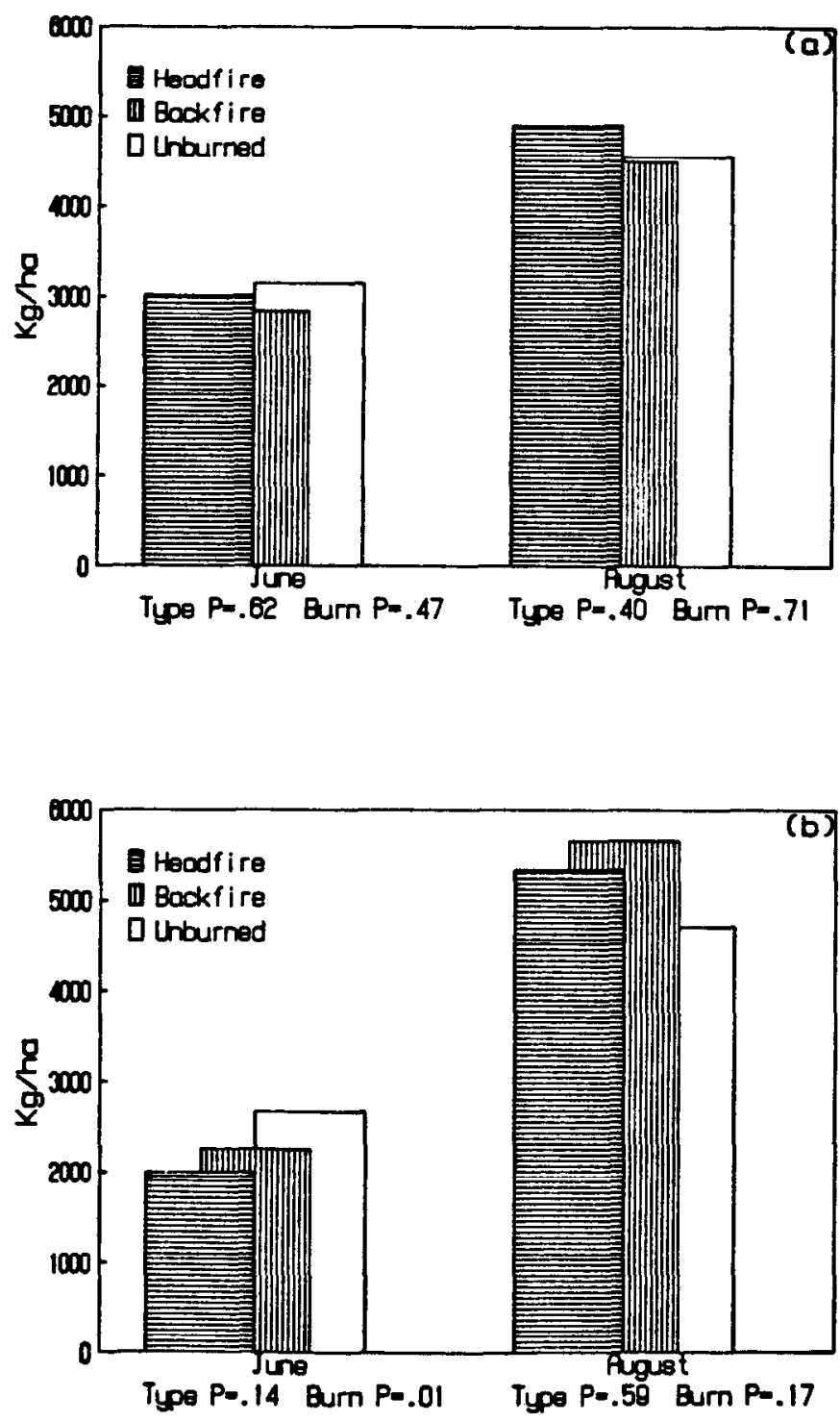

Fig. 2. Total standing crop in June and August of 1986 (a) and 1987 (b) on a shallow prairie range site in northcentral Oklahoma.

August because of adequate summer moisture. Towne and Owensby (1984) reported that neither long-term annual burning nor burning at the proper time in late spring will reduce productivity (end of season yield) in the tallgrass prairie of the Flint Hills of Kansas, but we measured a reduction of early season standing crop following late spring burning in a dry spring. Tallgrass prairie species composition is responsive to burning, but peak or post-peak standing crop is unaffected by burning, including late summer wildfire (Ewing and Engle 1988). The reduced early growing season standing crop we measured in burned plots in 1987 may have resulted from reduced water available to plants following burning (Hulbert 1969 , Owensby 1973 , Peterson 1983), coupled with abnormally dry weather during the maximum tallgrass herbage growth period (Gillen and McNew 1987).

\section{Management Implications}

Fire type may be used with late spring burning to manipulate the standing crop of tallgrasses and forbs in the tallgrass prairie to meet different management objectives. Headfires produced $21 \%$ $\left(400 \mathrm{~kg} \mathrm{ha}^{-1}\right.$ ) more tallgrass standing crop in August than backfires and $40 \%\left(775 \mathrm{~kg} \mathrm{ha}^{-1}\right.$ more tallgrass standing crop in August than unburned plots. Therefore, late spring burning with headfires is an appropriate management strategy in tallgrass prairies when the primary land use is cattle grazing. Under this landuse scenerio, the backfired area should be minimized within the constraints of the fire prescription.

Most fire prescriptions to increase forbs for wildlife habitat improvement call for winter burning (Guthrey 1986, Landers and Mueller 1986). However, our data suggest that if late spring burning must be used, backfires will increase forbs. Forbs will increase only if the management unit was grazed in the previous year and fine fuel is discontinuous, resulting in both low and high fuel loads. Backfires increased forbs by $26 \%\left(98 \mathrm{~kg} \mathrm{ha}^{-1}\right)$ over headfired plots. Backfires also left areas of unburned herbaceous plant material. Unburned patches of standing plants are beneficial to nesting birds, such as bobwhite quail (Colinus virginianus) (Lehmann 1984). Advantages of late spring burning over fall or winter burning also include reduced loss of standing dry forage for livestock, reduced loss of food and cover for wildlife in winter and early spring, and reduced labor and equipment costs compared to burning in winter for wildlife habitat and spring for livestock forage quality improvement. The disadvantages of late spring backfires include lower production of forbs and legumes than winter burning (Towne and Owensby 1984) and destruction of birds' nests (e.g., wild turkey (Meleagris gallopavo).

The logistics of using either headfiring or backfiring techniques must be considered when planning a burn. Rates of spread in our study were about $2.7 \mathrm{~km}$ during a normal 6-hour burning period for headfires, unless the fire front is disrupted by large areas of discontinuous fine fuel or dissected topography. Backfires advanced only about $0.2 \mathrm{~km}$ during a 6 hour period, but the advance of the fire front is even more dependent than headfires on continuous fine fuel and undissected topography. Implementation of backfires requires more labor and has practical application only to small areas for wildlife habitat manipulation.

\section{Literature Cited}

Abrams, M.D., A.K. Knapp, and L.C. Hulbert. 1986. A ten-year record of aboveground biomass in a Kansas tallgrass prairie: effects of fire and topographic position. Amer. J. Bot. 73:1509-1515.

Adams, D.E., and R.C. Anderson. 1978. The response of central Oklahoma grassland to burning. Southwest. Natur. 23:623-632.

Ahlgren, C.E. 1960. Some effects of fire on reproduction and growth of vegetation in northeastern Minnesota. Ecology 41:431-445.

Ahlgren, I.F. 1974. The effect of fire on soil organisms. p. 47-92 In: T.T. Kozlowski and C.E. Ahlgren (eds.). Fire and Ecosystems. Academic Press, New York.

Armour, C.D., S.C. Bunting, and L.F. Neuenschwander. 1984. Fire intensity effects on the understory in ponderosa pine forests. J. Range Manage. 37:44-49.

Brage. T.B. 1982. Seasonal variation in fuel and fuel consumption by fires in bluestem prairie. Ecology 63:7-11.

Bragg, T.B., and L.C. Hulbert. 1976. Woody plant invasion of unburned Kansas bluestem prairie. J. Range Manage. 29:19-24.

Ewing, A.L., and D.M. Engle. 1988. Effects of late summer fire on tallgrass prairie microclimate and community composition. Amer. Midl. Nat. 120:212-223.

Gibson, D.J. 1988. Regeneration and fluctuation of tallgrass prairie vegetation in response to burning frequency. Bull. Torrey Bot. Club 115:1-12.

Gillen, R.L., and R.W. McNew. 1987. Seasonal growth rates of tallgrass prairie after clipping. J. Range Manage. 40:342-345.

Guthrey, F.S. 1986. Beef, brush, and bobwhites: quail management in cattle country. Caesar Kleberg Wildlife Research Institute, Texas A\&I Univ., Kingsville, Texas.

Griffin, G.F., and M.H. Friedel. 1984. Effects of fire on central Australian rangelands. $I$. Fire and fuel characteristics and changes in herbage and nutrients. Aust. J. Ecol. 9:381-393. 
Hollies, H.L. 1973. Management of wild turkey habitat in southern forest types. p. 245-252. In: G.C. Sanderson and H.C. Schult (eds.). Wild turkey management: current problems and programs. Missouri Chap. the Wildol. Sôc. and Univ. Missouri Press, Columbia.

Hulbert, L.C. 1969. Fire and litter effects in undisturbed bluestem prairie in Kansas. Ecology 50:874-877.

Humphrey, R.R. 1962. Range ecology. Ronald Press, New York.

Kuchler, A.W. 1964. Potential natural vegetation of the conterminous United States. Manual to accompany the map. Amer. Geo. Soc. Spec. Pub. 36.

Landers, J.L., and B.S. Mueller. 1986. Bobwhite quail management: a habitat approach. Misc. Pub. 6, Tall Timbers Res. Sta., Tallahassee, Fla.

Launchbaugh, J.L., and C.E. Owensby. 1978. Kansas rangelands: their management based on a half century of research. Kansas Agr. Exp. Sta. Bull. 622., Kansas State Univ., Manhattan.

Lehmann, V.W. 1984. Bobwhites in the Rio Grande Plain of Texas. Texas A\&M Univ. Press, College Station.

Meyers, H.R. 1982. Climatological data of Stillwater, Oklahoma 18931980. Okla. Agr. Exp. Sta. Res. Rep. P-821.

McMurphy, W.E., and K.L. Anderson. 1965. Burning Flint Hills range. J. Range Manage. 18:265-269.

Owensby, C.E. 1973. Burning true prairie. p. 1-4. In: L.C. Hulbert (ed.). Proc. Third Midwest Prairie Conf., Kansas State Univ., Manhattan.

Peterson, N.J. 1983. The effects of fire, litter, and ash on flowering in Andropogon gerardii. p. 21-24. In: R. Brewer (ed.). Proc. Eighth North American Prairie Conf. Western Michigan Univ., Kalamazoo.
Powell, J., F.R. Crow, and D.G. Wagner. 1978. Rangeland watershed water budget and grazing cattle waste nutrient cycling. Completion Report R-803735. U.S. Environmental Protection Agency, Ada, Okla.

Foweī, J., S.J. Stadier, and F.I. Claypool. 1986. Weather factors affecting 22 years of tallgrass prairie production and quality. J. Range Manage. 39:354-361.

Pyne, S.J. 1982. Fire in America: a cultural history of wildland and rural fire. Princeton Univ. Press, Princeton, N.J.

Robert, F.H., C.M. Britton, D.B. Wester, and R.G. Clark. 1988. Fire effects on tobosagrass and weeping lovegrass. J. Range Manage. 41:407-409.

Towne, G., and C.E. Owensby. 1983. Annual broomweed [Gutierrezia dracunculoides (D.C.)Blake] response to burning and mulch addition. J. Range Manage. 36:711-712.

Towne, G., and C.E. Owensby. 1984. Long-term effects of annual burning at different dates in ungrazed Kansas tallgrass prairie. J. Range Manage. 37:392-397.

USDA Soil Conservation Service. 1981. Land resource regions and major land resource areas of the United States. Agr. Handb. 296, USDA Soil Conserv. Serv. U.S. Gov. Print. Off., Washington, D.C.

Wolfe, C.W. 1972. Effects of fire on a sandhills grassland environment. Proc. Tall Timbers Fire Ecol. Conf. 12:241-255.

Wright, H.A., and A.W. Bailey. 1982. Fire ecology: United States and southern Canada. John Wiley, New York.

Van Wagner, C.E. 1973. Height of crown scorch in forest fires. Can. J. Forest Res. 3:373-378. 